\title{
Graduate Students Experiences of Learning Community in Relation to Self-Determined Motivation
}

\author{
Fikriye Eda Karacul \\ The University of Texas at Austin
}

\begin{abstract}
This study attempted to explore the effect of inter- and intra-personal perceptions and practices of graduate students on their academic motivation from a Self Determination Theory perspective. Students in a large research university were surveyed to determine whether there is any association between their sense of learning community, the need for relatedness, and their reasons to be in graduate school. This study provides evidence to support the importance of the fulfillment of the need to belong in learning community. Differences between international and noninternational students represented when they were engaged in their coursework as analyzed by using Ryan and Deci's (2000) Self Determination and Tajfel and Turner's (1979) Social Identity Theory.
\end{abstract}

Keywords: Self-determination, Social Identity, Learning Community, Graduate Students, International Students

\section{INTRODUCTION}

Each year thousands of students apply to graduate programs to boost their human capital, improve their lives, and further their careers. Goplerud (1980) mentioned the effect of adjustment to settling in a new life and developing social relations for graduate students. As they developed good relations with the faculty and peers, their performance was enhanced and stress decreased. New graduate students experience stress due to financial and social changes and to need to adapt to their program. They greatly benefit from peer support, as shown in a study of a peer mentoring system (Bowman \& Bowman, 1990). Despite the struggle to achieve balance in their lives, graduate students decide to continue their education even in anticipation of these changes due to their strong motivation to learn. As in all levels of learning, each student comes to class with different types of motivation, and an educator's main concern is how to create a learning environment to support and improve the motivation of students to get the most out of learning. Students' experiences across courses with their peers, teachers, and also with their family have an impact on their motivation and well-being.

It is important to understand how such students perceive their learning environment and what aspects affect their motivation, in order to develop more satisfactory learning environments. Thus, this study aims to see whether their social environments affect adult learners as much as younger students have been reported to be and whether their perceptions affect their motivation and performance in their studies.

\section{Motivation and Self Determination Theory}

Motivation has been seen as a key process in various endeavors for decades and has developed several different definitions. Motivation can be considered as the energy and willingness to be involved in the process of knowledge, exploring and playing with information towards an aim. Many theoretical constructs associated with motivation have been developed including attribution, self-efficacy, expectancy-value, achievement goal orientation, and self- 
determination theory. This study focuses on constructs from self-determination theory (SDT). Rather than taking a simple dichotomous view, Ryan and Deci (2000) presented a complex view of extrinsic motivation as composed of multiple dimensions, which are amotivation; external, introjected, identified, integrated regulation; and intrinsic motivation. Although intrinsic motivation is focused on the core of the work to be accomplished, extrinsic motivation has types that represent a continuum of autonomy.

Amotivated individuals neither feel any passion for the activity nor do they see any value in it, therefore their practices lack the intention to act (Ryan \& Deci, 2000). Ryan and Deci (2008) asserted that external regulation refers to engaging in an activity for utility value or to avoid negative outcomes. In introjected regulation, individuals feel some internal pressure for acting but still do not have the full intention to act (Sungur \&Senler, 2010). In the next form, a person with identified regulation is seen as somewhat internally motivated because the individual values the behavior or action, due to its personal importance (Ryan \& Deci, 2008; Reeve, 2009). The last form of extrinsic motivation involves integrated regulation in which a person has internalized the values and behaviors (Deci et al., 1991). The individual is involved in the activity with self-determination because the activity is important and, valuable personally; however enjoyment is not necessarily felt. There is a fine line between integrated regulation and intrinsic motivation. The intrinsically motivated person is involved in the activity for the pure pleasure of it and is thoroughly interested in the action for self-satisfaction rather than for any external outcome or utility value. Intrinsically motivated individuals do not consider work as a hassle; they can focus on it for a longer period, and approach it with creativity (Reeve, 2009).

Vallerand et al. (1992) proposed that having different levels of intrinsic motivation would reflect reality of humans better than simply thinking of intrinsic motivation as being either on or off. Vallerand et al. (1992) described intrinsic motivation to know as the pure joy of learning. Intrinsic motivation to know focuses on the learning outcome while intrinsic motivation towards accomplishment focuses on the pleasure one feels when achieving a goal. Intrinsic motivation to experience stimulation involves doing an activity for experiencing the stimulating feelings that happen during participation. According to Ryan and Deci (2000), one sub theory of Self Determination Theory, "Organismic Integration Theory", considers that three basic needs humans have are autonomy, relatedness, and competence. Autonomy refers to the need to have freedom of choice, to self-determinate one's actions without external pressure; relatedness is the need to connect with others and belong; competence is the need to feel qualified enough to meet one's challenges and to be effective. Recently, Beachboard et al. (2011) found that the satisfaction of the need for relatedness with peers and faculty positively affected intrinsic motivation among college students. Woodruff and Schallert (2008) claimed that before an action takes place, an individual's motivation changes first, reflecting how competent, related, and autonomous the individual feels. In their study on the motivational and experiential dynamics of psychological needs of college students, Sheldon and Schuler (2011) found that participants' experiences were directly related with their needs, such that students who felt a lack of connection strove for more friendships whereas those with higher needs for success strove for competence. When students feel connected to classmates and the instructor of a class, such a feeling can allow students to initiate and accept new experiences and challenges because they feel support and care for the difficulties they may encounter (Noddings, 2005). Having good relations with peers and instructors makes it easier to feel more comfortable, to move out of their comfort zone, and get challenged (Noddings, 2005). By contrast, feeling incompetent directly affects the internalization of behaviors and relatedness to others (Ryan \& Deci, 2002). College students in competitive, supportive learning 
environments perceive themselves more positively, more confident, and are intrinsically motivated (Faye \& Sharpe, 2008).

In sum, fulfillment of the three basic needs, competence, autonomy and relatedness, enhances performance and well-being, resulting in a better process and outcomes.

\section{Sense of Community and Social Identity}

In learning environments, a community exists through interpersonal relationships (Osterman, 2000). The interaction and shared practices of members of a community generate an emotional interconnection, a sense of community. A strong sense of community requires individuals to be responsible to each other, care about each member of the group, be able to trust one another, feel a sense of interdependency, have common goals to be achieved, common needs to be fulfilled, and develop a strong, sensible communication and empathy (Rovai \& Lucking, 2003). As expected, it was found to be one of the necessary components of schools, and led to improved academic success (Solomon et al., 1996). When a positive classroom community is established, students develop friendships, peers and the instructor value their ideas, and they feel pleasure from being in that learning environment and the learning itself (Tinto, 1993). There is also a strong positive connection among sense of belongingness and student engagement, higher intrinsic motivation, and higher competency values (Osterman, 2000). Each learning community includes several groups based on common interests, or characteristics.

By becoming involved in a social group, we define ourselves as part of that group, as ingroup. Social Identity Theory addresses how individuals identify themselves as a member of one group (ingroup), distinguished from others in another group (outgroup), the process of identification, and the outcomes they bring (Turner et al., 1987). It elucidates the process of group formation, identity differentiation, social comparison, and conflict (Tajfel \&Turner, 1979). Amiot and Sansfacon (2011) explored the self-determined motives that are associated with identifying with an ingroup, and the consequences of such identification. They found that self-determined motivations to identify with a group had a positive effect on well-being of group members, but intrinsic motivation and amotivation brought more negative consequences. Individuals with amotivation to identify with a group were even explained as possibly experiencing dis-identification, "being outside of the self."

People perceive the community/group they choose to be involved with better than other groups and see their competence as related to being a part of that ingroup (Ryan \& Deci, 2003). Amiot and Sansfacon (2011) explained the consequences of identification with an ingroup by integrating self-determined motivation and social identity. They found that self-determined identification in a social group brings positive outcomes. Laar, Derks, Ellemers, and Bleeker (2010) argued that valuing social identities actually protects societal outcomes, increasing well-being, motivation, and performance in low-status groups. In a classroom context, ingroup and outgroup differences would be considered based on the experiences of fellow graduate students and class observations. Non-European and non-native English-speaking international students are likely to experience negative feelings such as feeling outsiders, so they may identify themselves more with their home country or with other international students (Schmitt, Spears \& Branscombe, 2003). Schmitt et al. (2003) found that when noninternational students chose to identify with international students, discrimination negatively affected their self-esteem and psychological well-being. Most research has shown ingroup and outgroup context effects on ethnic minorities and in relatively younger students from different perspectives. However, not much research has been done with graduate students, perhaps 
because of the commonly held high expectations about graduate students who are seen as emerging professionals.

\section{Purpose}

This study set out to describe the personal interactions of graduate students within their academic social environment to explain their motivational experiences. Learning environments always provide a dynamic structure with each new group of students. Graduate classes often present a blend of various cultural and academic backgrounds. In this dynamic structure, I focused on the self and environment factors while taking a component of Self Determination Theory (SDT), feeling of relatedness, into consideration.

Hegarty (2011) stressed the lack of research and measurement about the experiences of graduate students and asserted the need to investigate adult learners further. This study reviews the current literature surrounding classroom experiences and sense of community, and the construct of self-determination theory, as well as test the applications of the theories by examining data related to the effect of intergroup relations on the academic motivation of graduate students.

\section{Participants}

\section{METHOD}

From various disciplines of a large research university, 248 graduate students (89 male, 121 female, 38 gender unknown) participated in this study. List-wise deletion was used for missing data. Demographics are reported in Table 1 for the participants who provided all responses. 
Table 1 Demographics

\begin{tabular}{|c|c|c|}
\hline & $\mathbf{N}$ & $\%$ \\
\hline $\begin{array}{l}\text { Gender } \\
\text { Male } \\
\text { Female } \\
\text { Missing } \\
\text { Total }\end{array}$ & $\begin{array}{l}89 \\
121 \\
38 \\
248 \\
\end{array}$ & $\begin{array}{l}35.9 \\
48.8 \\
15.3 \\
100.0 \\
\end{array}$ \\
\hline $\begin{array}{l}\text { Age } \\
19-23 \\
24-29 \\
30-35 \\
36-42 \\
43 \text {-more } \\
\text { Missing } \\
\text { Total }\end{array}$ & $\begin{array}{l}15 \\
100 \\
51 \\
25 \\
19 \\
38 \\
248 \\
\end{array}$ & $\begin{array}{l}6.0 \\
40.3 \\
20.6 \\
10.1 \\
7.7 \\
15.3 \\
100.0\end{array}$ \\
\hline $\begin{array}{l}\text { Status } \\
\text { International } \\
\text { Not-international } \\
\text { Missing } \\
\text { Total } \\
\end{array}$ & $\begin{array}{l}45 \\
165 \\
38 \\
248 \\
\end{array}$ & $\begin{array}{l}18.1 \\
66.5 \\
15.3 \\
100.0 \\
\end{array}$ \\
\hline $\begin{array}{l}\text { Discipline } \\
\text { Business } \\
\text { Communication } \\
\text { Education } \\
\text { Engineering } \\
\text { Liberal Arts } \\
\text { Natural Sciences } \\
\text { other } \\
\text { Missing } \\
\text { Total }\end{array}$ & $\begin{array}{l}27 \\
39 \\
22 \\
25 \\
55 \\
35 \\
7 \\
38 \\
248\end{array}$ & $\begin{array}{l}10.9 \\
15.7 \\
8.9 \\
10.1 \\
22.2 \\
14.1 \\
2.8 \\
15.3 \\
100.0\end{array}$ \\
\hline $\begin{array}{l}\text { Ethnicity } \\
\text { Native-American(Indigenous) } \\
\text { Asian-American/Oriental/Pacific Islander } \\
\text { Asian } \\
\text { Black/African-American/African descent } \\
\text { Mexican-American/Chicano/Latino } \\
\text { Puerto-Rican } \\
\text { Hispanic/Latino descent } \\
\text { White-European descent } \\
\text { White-Middle eastern descent } \\
\text { Multiple ethnic groups } \\
\text { Other } \\
\text { Missing } \\
\text { Total }\end{array}$ & $\begin{array}{l}2 \\
4 \\
19 \\
5 \\
10 \\
1 \\
5 \\
133 \\
13 \\
16 \\
2 \\
38 \\
210\end{array}$ & $\begin{array}{l}.8 \\
1.6 \\
7.7 \\
2.0 \\
4.0 \\
.4 \\
2.0 \\
53.6 \\
5.2 \\
6.5 \\
.8 \\
15.3 \\
100.0\end{array}$ \\
\hline
\end{tabular}

\section{Measures}

The survey consisted of two research instruments and some demographic questions which is detailed below:

The Learning Community Scale: This instrument was composed of items from three different scales, the Basic Needs Satisfaction in Your College Course, the Sense of Classroom Community, and the Academic Classroom Community Scales created by Bush et al. (2004), Bush (2006), Summers et al. (2005). The Cronbach alpha values of the original scales ranged from .66 to .92, with the majority items having good level of internal consistency. In addition to adjusting these scales to the purpose of the study, four items were added. Each item was rated on a 7-point likert scale, ranging from 1 (strongly disagree) to 7 (strongly agree). The distributed version of the total instrument contained 34 items; however after factor analysis, 28 items remained for data analysis. 
Academic Motivation Scale (AMS-C): This scale was originally developed by Vallerand et al. (1992), and consists of 28 items aiming to measure what type of motivation students are experiencing throughout their learning experiences. Vallerand identified 7 categories of motivation which underlie the well-known intrinsic, extrinsic, and amotivation, with a Likert scale ranging from 1 (strongly disagree) to 7 (strongly agree). In this study, the scale was changed to 1 (not true of me at all) to 7 (exactly true of me). In the scale, intrinsic motivation is divided into "to know, to accomplish things, to experience stimulation," extrinsic motivation is divided into "external, introjected, identified regulation," with amotivation its own category. Because the original scale was developed for college students, minor changes were completed to fit the sample of graduate students. The original scale had an internal consistency of .81, test-retest correlation ranging from .71 to .83 , indicating that the scale is reliable and valid (Vallerand et al., 1992).

\section{Statistical Analyses}

Initially factor analysis was conducted on the Learning Community Questionnaire for defining which items worked best for the participants, and which ones composed clusters. Next, the average scores for each factor were calculated for further analysis. Independent samples t-test was used to compare the means of groups and check whether there were any difference between groups on any factor.

For the Academic Motivation survey, the average scores for each of the seven motivation types were calculated per student. Then, t-tests were run using SPSS to check for differences between, men and women, and between international and non-international students.

After the factor analysis, reliability analyses were calculated for both scales. Then, bivariate correlation analyses were conducted with SPSS between the two questionnaires to determine the kinds of relations that existed within and between subscale scores. Lastly, analyses on each of the variables were conducted for a number of the demographic factors captured in the questionnaire. For two categorical demographic variables (e.g. gender, international status), ttests and for demographic variables with more than two categories (e.g. age, discipline) oneway Anova were conducted to determine if there were significant differences among the subsamples. For each of the ANOVA calculations, a test for homogeneity of variance was conducted and is reported along with each of the ANOVA outcomes. Additionally Tukey's post-hoc procedure was used to see which means were significantly different from the other.

\section{RESULTS}

Findings were presented beginning with the factor analysis of the Learning Community Questionnaire, followed by reliabilities for both scales in the survey. Then, the findings are addressed as related to each research question.

\section{Factor Analysis for Learning Community Questionnaire}

Initially questionnaire consisted of 34 items of which 4 items $(17,19,20$, and 21$)$ were selfcreated and other items were taken from different scales intending to measure the idea of learning community. Therefore, to select the best fitting items for analysis and to make interpretation of results clearer, an exploratory factor analysis is conducted with principal components and varimax rotation analysis with a .40 absolute value cut point. KMO value of 0.90 and a significant Barlett's Test of Sphericity proved that the data were suitable for factor analysis. With confidence in the results of KMO and Barlett's Test (Table 2), a three-component solution is used until reaching the final factors. As a result, Learning Community Questionnaire was composed of 28 items in which "Factor 1-Classroom Community" had 13 items. Items with negative loadings $(26,31$, and 32) were reverse scored for next analyses. "Factor 2-Positive 
Support and Respect" had 9 items, and "Factor 3-Feeling Distressed" had 6 items. All items in the last factor had negative meanings, with positive factor loadings therefore, instead of using reverse coding, factor 3 is given a negative name; "feeling distressed by situations or others."

Table 2 KMO and Bartlett's Test

\begin{tabular}{|l|l|l|}
\hline Kaiser-Meyer-Olkin Measure of Sampling Adequacy. & .900 \\
\hline Bartlett's Test of Sphericity & Approx. Chi-Square & 3696.084 \\
\cline { 2 - 3 } & df & 378 \\
\cline { 2 - 3 } & Sig. & .000 \\
\hline
\end{tabular}


Table 3 Factor Loadings for Learning Community Questionnaire

\begin{tabular}{|c|c|c|c|}
\hline & \multicolumn{3}{|c|}{ Component } \\
\hline & $\begin{array}{l}\text { Classroom } \\
\text { Community }\end{array}$ & $\begin{array}{l}\text { Positive } \\
\text { Support \& } \\
\text { Respect }\end{array}$ & $\begin{array}{l}\text { Feeling Distressed by } \\
\text { others/situations }\end{array}$ \\
\hline $\begin{array}{l}\text { 31. In most of my classes, there are not many people that I am } \\
\text { close to. }\end{array}$ & -.808 & & \\
\hline $\begin{array}{l}\text { 27. I consider the people I regularly interact with in most of my } \\
\text { classes to be my friends. }\end{array}$ & .791 & & \\
\hline 16. I know other people well in most of my classes. & .768 & & \\
\hline 29. People in most of my classes care about me. & .752 & & \\
\hline $\begin{array}{l}\text { 18. In most of my classes, I feel connected to the other students } \\
\text { and the teacher. }\end{array}$ & .732 & & \\
\hline 22. In most of my classes, I really like the people I interact with. & .720 & & \\
\hline $\begin{array}{l}\text { 1. In most of my classes, I make friends with and get to know } \\
\text { others in the class. }\end{array}$ & .717 & & \\
\hline $\begin{array}{l}\text { 26. I pretty much keep to myself and don't have a lot of social } \\
\text { contacts in most of my classes. }\end{array}$ & -.697 & & \\
\hline $\begin{array}{l}\text { 34. Other students in my classes are generally pretty friendly } \\
\text { towards me. }\end{array}$ & .694 & & \\
\hline 15. In most of my classes, I feel I fit in. & .691 & & \\
\hline $\begin{array}{l}\text { 6. In most of my classes, the other students in class make me feel } \\
\text { welcome. }\end{array}$ & .687 & & \\
\hline $\begin{array}{l}\text { 25. I get along with people I come into contact with in most of my } \\
\text { classes. }\end{array}$ & .674 & & \\
\hline $\begin{array}{l}\text { 32. The people I interact with regularly in my courses do not } \\
\text { seem to like me much. }\end{array}$ & -.634 & & \\
\hline $\begin{array}{l}\text { 10. In most of my classes, interactions with my instructors are } \\
\text { generally positive. }\end{array}$ & & .792 & \\
\hline $\begin{array}{l}\text { 2. In most of my classes I feel as though my instructor respect } \\
\text { each student. }\end{array}$ & & .788 & \\
\hline $\begin{array}{l}\text { 7. In most of my classes, the relationship between the instructor } \\
\text { and students is comfortable. }\end{array}$ & & .755 & \\
\hline $\begin{array}{l}\text { 13. In most of my classes, the instructor supports students' } \\
\text { comments. }\end{array}$ & & .732 & \\
\hline 3. In most of my classes, students' value other's opinions. & & .672 & \\
\hline $\begin{array}{l}\text { 5. In most of my classes, the instructor gives me positive } \\
\text { feedback when I make a comment in class. }\end{array}$ & & .663 & \\
\hline 9. In most of my classes, I respect my classmates. & & .562 & \\
\hline $\begin{array}{l}\text { 28. I have been able to learn interesting new skills in most of my } \\
\text { classes recently. }\end{array}$ & & .455 & \\
\hline $\begin{array}{l}\text { 12. In most of my classes, I value each student's contribution to } \\
\text { the class. }\end{array}$ & & .432 & \\
\hline 23. Often, I do not feel very competent in many of my classes. & & & .714 \\
\hline 33. I do not feel very capable in most of my classes. & & & .702 \\
\hline $\begin{array}{l}\text { 20. In small group discussions, I feel uncomfortable being in the } \\
\text { same group with unfamiliar students. }\end{array}$ & & & .657 \\
\hline $\begin{array}{l}\text { 19. I avoid asking questions if most of the people in a course are } \\
\text { unfamiliar to me. }\end{array}$ & & & .618 \\
\hline
\end{tabular}


30. In most of my classes I do not get much of a chance to show how capable I am.

21. I feel uncomfortable when the instructor or other students mention a topic or example that I don't understand because it is culturally unfamiliar to me.

\section{Correlation Analyses of Survey Measures}

Internal consistency calculations were conducted for both scales. Based on the reliability calculations using 248 participants responses, the learning community scale had most of the subscales performing very well, with coefficient alphas equal to or larger than 0.70 . An overall reliability analysis with 28 items resulted in a Cronbach's $\alpha$ value of .81 representing a highly reliable scale. Reliability analysis of the Academic Motivation Scale was high $(\alpha=.81)$, with intrinsic motivation subscales being around .85 alpha levels. Extrinsic motivation-identified at $\alpha=.72$ and external regulation at $\alpha=.77$ showed acceptable internal consistency and introjected external motivation and amotivation subscales had good reliability levels, having $\alpha=.85$ or more.

\section{Findings as related to each research question}

\section{Will graduate students' self-determined motivation be associated with the nature of} their perceptions of the interactions they have with classmates and the instructor in class? Students' interactions with their classmates and instructors were measured by the subscales measuring Learning Community, with its three factors of Classroom Community, Positive Support And Respect, And Feeling Distressed (factors 1, 2, and 3). Bivariate correlation analyses were conducted on all of the instruments. The results of the Pearson correlation analyses are presented in Table 4. 
Table 4 Intercorrelations among Questionnaire-1 and Questionnaire-2 subscales

\begin{tabular}{|c|c|c|c|c|c|c|c|c|c|c|}
\hline & 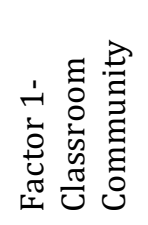 & 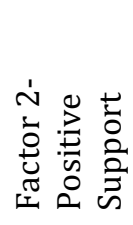 & 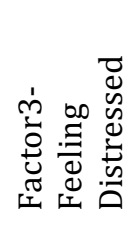 & 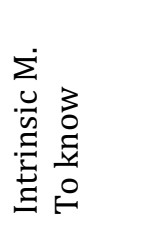 & 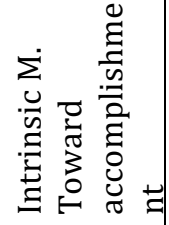 & 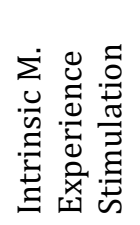 & 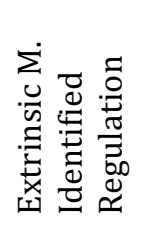 & 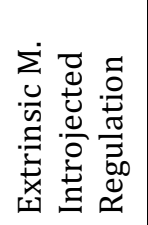 & 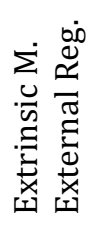 & 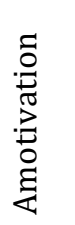 \\
\hline $\begin{array}{l}\text { Factor 1-Classroom } \\
\text { Community }\end{array}$ & 1 & & & & & & & & & \\
\hline $\begin{array}{l}\text { Factor 2- Positive } \\
\text { Support }\end{array}$ & $.456^{* *}$ & 1 & & & & & & & & \\
\hline $\begin{array}{l}\text { Factor 3-Feeling } \\
\text { Distressed }\end{array}$ & $-.337^{* *}$ & $-.209^{* *}$ & 1 & & & & & & & \\
\hline $\begin{array}{l}\text { Intrinsic M.- } \\
\text { to know }\end{array}$ & $.092^{* *}$ & $.208^{* *}$ & $-.170^{*}$ & 1 & & & & & & \\
\hline $\begin{array}{l}\text { Intrinsic M.-toward } \\
\text { accomplishment }\end{array}$ & .090 & $.172^{*}$ & -.037 & $.736^{* *}$ & 1 & & & & & \\
\hline $\begin{array}{l}\text { Intrinsic M- } \\
\text { experience } \\
\text { stimulation }\end{array}$ & .065 & .066 & .017 & $.645^{* *}$ & $.654^{* *}$ & 1 & & & & \\
\hline $\begin{array}{l}\text { Extrinsic M.- } \\
\text { Identified } \\
\text { Regulation }\end{array}$ & $.183^{* *}$ & $.237^{* *}$ & .101 & .133 & $.138^{*}$ & .076 & 1 & & & \\
\hline $\begin{array}{l}\text { Extrinsic M.- } \\
\text { Introjected } \\
\text { Regulation }\end{array}$ & .032 & -.006 & $.206^{* *}$ & $.285^{* *}$ & $.503^{* *}$ & $.338^{* *}$ & $.229^{* *}$ & 1 & & \\
\hline $\begin{array}{l}\text { Extrinsic M.- } \\
\text { External } \\
\text { Regulation }\end{array}$ & -.018 & .000 & $.307^{* *}$ & $-.176^{*}$ & -.102 & -.072 & $-.514^{* *}$ & $.313^{* *}$ & 1 & \\
\hline Amotivation & $-.224^{* *}$ & $-.326^{* *}$ & $.262^{* *}$ & $-.272^{* *}$ & $-.235^{* *}$ & -.047 & $-.213^{* *}$ & .074 & .095 & 1 \\
\hline
\end{tabular}

$*$ Correlation is significant at the .05 level (2-tailed).

** Correlation is significant at the .01 level (2-tailed).

The results showed that the classroom community subscale was positively correlated with the intrinsic motivation to know ( $\mathrm{r}=.092, \mathrm{p}<.01)$, identified regulation subscale $(\mathrm{r}=.183, \mathrm{p}<.01)$, whereas it had a significant negative correlation with the amotivation subscale $(\mathrm{r}=-.224$, $\mathrm{p}<.01)$. Positive support and respect from peers and instructors was significantly correlated with the two intrinsic motivation subscales, to know $(\mathrm{r}=.208, \mathrm{p}<.01)$, and to experience stimulation $(\mathrm{r}=.172, \mathrm{p}<.05)$, and with the extrinsic motivation-identified regulation subscale $(\mathrm{r}=.237, \mathrm{p}<.01)$, and it was negatively associated with amotivation $(\mathrm{r}=-.326, \mathrm{p}<.01)$. The subscale, feeling distressed by others or situations, showed significant positive correlations with two extrinsic motivation subscales, introjected $(\mathrm{r}=.206, \mathrm{p}<.01)$ and external regulation $(\mathrm{r}=.307$, $\mathrm{p}<.01)$, and with the amotivation subscale $(\mathrm{r}=.262, \mathrm{p}<.01)$, and it had a significant negative correlation with intrinsic motivation- to know subscale $(\mathrm{r}=-.170, \mathrm{p}<05)$.

\section{Will international students be more affected than non-international students by the use of culturally local examples or experiences used by the instructor or other students in instruction?}

The overall results indicated significant differences between international students and noninternational students on the extrinsic motivation-external regulation subscale $(\mathrm{t}=-2.018$, $\mathrm{F}=.214, \mathrm{p}<.05)$ and the classroom community subscales $(\mathrm{t}=-3.45, \mathrm{~F}=3.265, \mathrm{p}<.01)$. International students mean scores were slightly higher than non-internationals on the intrinsic motivation types and lower on the classroom community subscale. However, one specific item on the surveys addressed the research question pointedly: "I feel uncomfortable 
when the instructor or other students mention a topic or example that I don't understand because it is culturally unfamiliar to me". On that specific item, international students scored significantly higher than non-international students $(\mathrm{t}=4.40, \mathrm{~F}=9.39, \mathrm{p}<.01)$, indicating that international students feel more uncomfortable than others when the instructor or peers use culturally local examples.

International students reported significantly lower levels of external regulation and lower levels of classroom community then non-international students. No significant differences existed between international status on any of the remaining measures. The means are presented at Table 5.

Table 5 Survey Outcomes for Means by Internationals and Non-internationals

\begin{tabular}{|l|c|c|}
\hline & International & Non-international \\
\hline Factor1_classroom community** & $\mathrm{N}=45$ & $\mathrm{~N}=165$ \\
\hline Factor2_positive support \& respect & 4.72 & 5.27 \\
\hline Factor3_feeling distressed & 5.71 & 5.74 \\
\hline Intrinsic M.-to know & 3.08 & 2.82 \\
\hline Intrinsic M.-toward accomplishment & 6.03 & 5.88 \\
\hline Intrinsic M-experience stimulation & 5.45 & 5.17 \\
\hline Extrinsic M-identified regulation & 4.98 & 4.54 \\
\hline Extrinsic M-introjected regulation & 5.31 & 5.53 \\
\hline Extrinsic M-external regulation* & 4.15 & 4.49 \\
\hline Amotivation & 3.97 & 4.44 \\
\hline
\end{tabular}

\section{Are higher levels of feeling ingroup during a class associated with higher scores on the intrinsic motivation scales and with lower scores on the extrinsic motivation and amotivation subscales?}

The mean scores on the subscales of classroom community and positive support is used as an indicator of feelings of ingroup. Students who scored higher on these two subscales were expected to report higher feelings of ingroup in the learning environment. The subscale for feeling distressed by others or situations was defined as feeling outgroup. The Survey Outcomes for Means by Ingroup/Outgroup were presented at Table 6.

The results revealed a positive association between feeling ingroup and experiencing higher levels of intrinsic motivation to know $(\mathrm{r}=.158, \mathrm{p}<.05)$, towards accomplishment $(\mathrm{r}=.141$, $\mathrm{p}<.05)$, and identified regulation $(\mathrm{r}=.23, \mathrm{p}<.01)$. Feeling outgroup was associated positively with introjected regulation $(\mathrm{r}=.21, \mathrm{p}<.01)$ and external regulation $(\mathrm{r}=.31, \mathrm{p}<.01)$, and negatively with intrinsic motivation to know $(r=-.170, \mathrm{p}<.05)$. 
Table 6 Survey Outcomes for Means by Ingroup/Outgroup

\begin{tabular}{|c|c|c|c|}
\hline \multicolumn{4}{|c|}{ Descriptive Statistics } \\
\hline & Mean & Std. Deviation & $\mathrm{N}$ \\
\hline Feeling Ingroup & 5.43 & .72 & 248 \\
\hline Feeling Outgroup & 2.92 & .93 & 248 \\
\hline Intrinsic motivation to know & 5.90 & .91 & 214 \\
\hline Intrinsic motivation towards accomplishment & 5.21 & 1.20 & 214 \\
\hline Intrinsic motivation to experience stimulation & 4.63 & 1.40 & 214 \\
\hline Extrinsic M.-Identified Regulation & 5.49 & 1.08 & 214 \\
\hline Extrinsic M.-Introjected Regulation & 4.40 & 1.54 & 214 \\
\hline Extrinsic M.-External Regulation & 4.35 & 1.40 & 214 \\
\hline
\end{tabular}

\section{Are there any differences on the learning community and self-determined motivation} subscales between groups representing gender, age levels, disciplines, ethnicity, and years spent in graduate school?

t-test for gender: Significant differences $(\mathrm{df}=208)$ did not exist between men and women on any the subscales of the Learning Community Questionnaire, for classroom community $(\mathrm{t}=.195$, $\mathrm{p}>.05)$, positive support and respect ( $\mathrm{t}=1.00, \mathrm{p}>.05)$, and feeling distressed $(\mathrm{t}=-1.47, \mathrm{p}>.05)$. Also, no significant differences existed between men and women on subscales of Academic Motivation Questionnaire (intrinsic motivation, extrinsic, amotivation). The Survey Outcomes for Means by Gender are presented at Table 7.

Table 7 Survey Outcomes for Means by Gender

\begin{tabular}{|l|r|r|}
\hline & Male & Female \\
\hline & $\mathrm{N}=89$ & $\mathrm{~N}=121$ \\
\hline Factor 1-classroom community & 5.17 & 5.14 \\
\hline Factor 2-positive support \& respect & 5.78 & 5.69 \\
\hline Factor 3-feeling distressed & 2.77 & 2.95 \\
\hline Intrinsic M-to know & 5.94 & 5.90 \\
\hline Intrinsic M-toward accomplishment & 5.20 & 5.25 \\
\hline Intrinsic M-experience stimulation & 4.55 & 4.70 \\
\hline Extrinsic M-identified regulation & 5.49 & 5.48 \\
\hline Extrinsic M-introjected regulation & 4.35 & 4.33 \\
\hline Extrinsic M-external regulation & 4.35 & 4.33 \\
\hline Amotivation & 1.75 & 1.87 \\
\hline
\end{tabular}

One-way Anova for age: The majority of the participants $(\mathrm{n}=100)$ were between ages 24 to 29 years, followed by $30-35$ years $(n=51)$. Significant differences $(d f 4,205)$ existed for age on the Factor2-positive support and respect $(F=2.953, p<.05)$, Factor3-feeling distressed $(\mathrm{F}=2.529$, $\mathrm{p}<.05)$, and amotivation $(F=3.807, p<.01)$ subscales. No significant differences existed among age groups on the remaining measures. The test of homogeneity of variances was significant only for the amotivation subscale. Results of the mean scores for all measures are found in Table 8.

To see among which pairs the significant differences lay, a Tukey's Post-Hoc procedure was conducted. On the amotivation subscale, the age group 19 to 23 years was significantly higher 
than the 30 to 35 years and 43 years or more groups $(\mathrm{p}<.05)$. On factor2-positive support and respect, the 19-23 age group scored significantly lower than the 43-more age group and the 24-29 age group scored significantly higher than 43 or more years individuals $(\mathrm{p}<.05)$. On factor3-feeling distressed subscale, the age group 19-23 years scored significantly higher than 43-more age group.

Table 8 Survey Outcomes for Means by Age

\begin{tabular}{|c|c|c|c|c|c|c|}
\hline & $\begin{array}{l}19-23 \\
N=15\end{array}$ & $\begin{array}{l}24-29 \\
N=100\end{array}$ & $\begin{array}{l}30-35 \\
N=51\end{array}$ & $\begin{array}{l}36-42 \\
N=25\end{array}$ & $\begin{array}{l}\text { 43\&more } \\
N=19\end{array}$ & $\begin{array}{l}\text { Total } \\
\mathrm{N}=210\end{array}$ \\
\hline Factor1-Classroom Community & 5.16 & 5.12 & 5.17 & 5.00 & 5.43 & 5.15 \\
\hline Factor2-Positive Support and Respect* & 5.48 & 5.65 & 5.78 & 5.80 & 6.13 & 5.73 \\
\hline Factor3-Feeling Distressed * & 3.43 & 2.91 & 2.82 & 2.80 & 2.47 & 2.87 \\
\hline Intrinsic M.- to know & 6.03 & 5.84 & 5.96 & 5.99 & 5.93 & 5.91 \\
\hline Intrinsic M.- towards Accomplishment & 5.17 & 5.24 & 5.24 & 5.24 & 5.14 & 5.22 \\
\hline Intrinsic M.- experience Stimulation & 4.60 & 4.53 & 4.82 & 4.78 & 4.57 & 4.63 \\
\hline Extrinsic M.- identified regulation & 5.27 & 5.44 & 5.70 & 5.52 & 5.26 & 5.48 \\
\hline Extrinsic M.- introjected regulation & 4.47 & 4.49 & 4.28 & 4.86 & 3.82 & 4.42 \\
\hline Extrinsic M.- external Regulation & 4.57 & 4.37 & 4.47 & 4.43 & 3.54 & 4.34 \\
\hline Amotivation ** & 2.50 & 1.93 & 1.58 & 1.83 & 1.32 & 1.82 \\
\hline
\end{tabular}

${ }^{*} \mathrm{p}<.05 ;{ }^{* *} \mathrm{p}<.01$

Independent Samples t-test for ethnicity: On this analysis the Classroom Community subscale showed significant mean differences between the two groups $(\mathrm{t}=-2.379, \mathrm{~F}=.611, \mathrm{p}<.05)$. European decent white students reported significantly higher levels of classroom community than non-European descent students (Table 9).

Table 9 Survey Outcomes for Means by Ethnicity

\begin{tabular}{|l|r|r|}
\hline & $\begin{array}{c}\text { Non-European } \\
\text { descent }\end{array}$ & $\begin{array}{c}\text { White-European } \\
\text { descent }\end{array}$ \\
\hline & $\mathrm{N}=77$ & $\mathrm{~N}=133$ \\
\hline Factor1_classroom community* & 4.94 & 5.27 \\
\hline Factor2_positive support \& respect & 5.75 & 5.72 \\
\hline Factor3_feeling distressed & 3.00 & 2.80 \\
\hline Intrinsic M.-to know & 5.81 & 5.97 \\
\hline Intrinsic M.-toward accomplishment & 5.29 & 5.19 \\
\hline Intrinsic M-experience stimulation & 4.62 & 4.64 \\
\hline Extrinsic M-identified regulation & 5.47 & 5.49 \\
\hline Extrinsic M-introjected regulation & 4.35 & 4.46 \\
\hline Extrinsic M-external regulation & 4.44 & \\
\hline Amotivation & 1.90 & \\
\hline
\end{tabular}

${ }^{*} \mathrm{p}<.05 ;{ }^{* *} \mathrm{p}<.01$

One-way Anova for discipline: Significant differences $(d f 6,203)$ existed among disciplines on the Intrinsic Motivation-towards accomplishment $(\mathrm{F}=2.402, \mathrm{p}<.05)$ and to experience stimulation $(\mathrm{F}=3.226, \mathrm{p}<.01)$, Extrinsic Motivation-identified regulation $(\mathrm{F}=2.696, p<.05)$ subscales. No significant differences existed among disciplines on the remaining measures. The 
test of homogeneity of variances was significant for intrinsic motivation-toward accomplishment and extrinsic motivation-identified regulation, external regulation and factor 1-classroom community subscales. Results of the mean scores for all measures are found in Table 10.

Although the ANOVA result indicated a significant overall $\mathrm{F}$ for the subscale, Tukey HSD posthoc procedure did not present any significant differences for intrinsic motivation- towards accomplishment subscale. Education majors were significantly higher on the intrinsic motivation to experience stimulation subscale than natural science majors ( $\mathrm{p}<.05)$, and natural science majors were significantly lower on that scale than liberal arts majors. On the extrinsic motivation-identified regulation subscale, education majors had significantly higher mean scores than engineering majors $(\mathrm{p}<.05)$, whereas engineering majors scored significantly lower than natural science majors on that subscale.

Table 10 Survey Outcomes for Means by Discipline

\begin{tabular}{|c|c|c|c|c|c|c|}
\hline & $\begin{array}{l}\text { Business } \\
\text { N=27 }\end{array}$ & $\begin{array}{l}\text { Communication } \\
\qquad \mathrm{N}=39\end{array}$ & $\begin{array}{l}\text { Education } \\
\qquad \mathrm{N}=22\end{array}$ & $\begin{array}{l}\text { Engineering } \\
\qquad \mathrm{N}=25\end{array}$ & $\begin{array}{c}\text { Liberal } \\
\text { Arts } \\
\mathrm{N}=55\end{array}$ & $\begin{array}{c}\text { Natural } \\
\text { Sciences } \\
\mathrm{N}=35\end{array}$ \\
\hline $\begin{array}{l}\text { Factor1-Classroom } \\
\text { Community }\end{array}$ & 5.21 & 5.00 & 5.05 & 4.96 & 5.29 & 5.32 \\
\hline $\begin{array}{l}\text { Factor2-Positive Support and } \\
\text { Respect }\end{array}$ & 5.65 & 5.78 & 5.96 & 5.62 & 5.64 & 5.79 \\
\hline Factor3-Feeling Distressed & 2.76 & 2.67 & 3.20 & 3.01 & 2.85 & 2.92 \\
\hline Intrinsic M.- to know & 5.69 & 5.94 & 6.13 & 5.78 & 6.13 & 5.70 \\
\hline $\begin{array}{l}\text { Intrinsic M.- towards } \\
\text { Accomplishment }\end{array}$ & 4.75 & 5.00 & 5.73 & 5.33 & 5.51 & 5.08 \\
\hline $\begin{array}{c}\text { Intrinsic M.- experience } \\
\text { Stimulation* }\end{array}$ & 4.40 & 4.43 & $5.16^{*}$ & 4.41 & $5.12^{*}$ & $4.06^{*}$ \\
\hline $\begin{array}{l}\text { Extrinsic M.- identified } \\
\text { regulation* }\end{array}$ & 5.42 & 5.39 & $6.00^{*}$ & $5.02^{*}$ & 5.45 & $5.81^{*}$ \\
\hline $\begin{array}{l}\text { Extrinsic M.-introjected } \\
\text { Regulation }\end{array}$ & 3.74 & 4.33 & 4.90 & 4.39 & 4.43 & 4.71 \\
\hline $\begin{array}{l}\text { Extrinsic M.- external } \\
\text { Regulation }\end{array}$ & 4.44 & 4.17 & 4.51 & 4.14 & 4.38 & 4.64 \\
\hline Amotivation & 1.78 & 1.94 & 1.60 & 1.60 & 1.99 & 1.76 \\
\hline
\end{tabular}

${ }^{*} \mathrm{p}<.05 ;{ }^{* *} \mathrm{p}<.01$

One-way Anova for number of years in graduate school: Significant differences $(d f 4,205)$ existed among groups of students with different years in graduate school on the Factor2positive support and respect $(F=4.95, p<.01)$, Extrinsic Motivation-introjected regulation $(\mathrm{F}=2.60, p<.05)$, and Extrinsic Motivation-external regulation $(F=2.596, p<.05)$ subscales. No significant differences existed among number of years in graduate school on the remaining measures. The test of homogeneity of variances was not significant for any of the scales. Results of the mean scores for all measures are presented in Table 11.

The Tukey's HSD results showed that graduate students in their first, second, and fifth year or more were significantly higher on the positive support subscale than were fourth year students $(\mathrm{p}<.05)$, with first year students having the highest mean score (5.89). Post-hoc test results did not give any significant differences among the groups formed by number of years in graduate 
school on introjected regulation and external regulation subscales even though the overall ANOVAs had indicated significant results.

Table 11 Survey Outcomes for Means by Years in Graduate School

\begin{tabular}{|l|r|r|r|r|r|r|}
\hline & \multicolumn{1}{|c|}{$\begin{array}{c}1 \\
\mathrm{~N}=69\end{array}$} & $\begin{array}{c}\mathrm{N}=57 \\
\mathrm{~N}=33\end{array}$ & $\begin{array}{c}4 \\
\mathrm{~N}=20\end{array}$ & $\begin{array}{c}5 \text { or more } \\
\mathrm{N}=31\end{array}$ & $\begin{array}{c}\text { Total } \\
\mathrm{N}=210\end{array}$ \\
\hline Factor1-Classroom Community & 5.36 & 5.05 & 4.97 & 4.76 & 5.29 & 5.15 \\
\hline Factor2_Positive Support and Respect** & 5.89 & 5.74 & 5.70 & 5.17 & 5.73 & 5.73 \\
\hline Factor3_Feeling Distressed & 3.10 & 2.79 & 2.84 & 2.85 & 2.58 & 2.87 \\
\hline intrinsic1_to know & 5.76 & 6.13 & 5.93 & 5.57 & 6.06 & 5.91 \\
\hline intrinsic2_towards Accomplishment & 5.12 & 5.46 & 5.22 & 4.71 & 5.35 & 5.23 \\
\hline intrinsic3_experience Stimulation & 4.48 & 4.82 & 4.66 & 4.64 & 4.64 & 4.64 \\
\hline extrinsic1_identified & 5.69 & 5.45 & 5.26 & 4.99 & 5.64 & 5.48 \\
\hline extrinsic2_introjected * & 4.44 & 4.75 & 3.96 & 3.75 & 4.68 & 4.42 \\
\hline extrinsic3_external Regulation * & 4.65 & 4.41 & 3.88 & 3.77 & 4.35 & 4.34 \\
\hline Amotivation & 1.67 & 1.76 & 2.11 & 2.23 & 1.68 & 1.82 \\
\hline
\end{tabular}

\section{DISCUSSION}

\section{Will graduate students' self-determined motivation be associated with the nature of} their perceptions of interactions they have with classmates and the instructor in class?

The results of the bi-variate correlation analysis showed that students' positive sense of classroom community was associated with intrinsic motivation to know and identified regulation, and was negatively associated with amotivation supporting the hypothesis. Positive support and respect from peers and instructors were related to students' intrinsic motivation to know and to experience stimulation and to their identified regulation (extrinsic motivation), whereas again lack of positive support and respect were related to amotivation. Positive communication, support, respect, and being prepared before class were seen as some major prerequisites to form classroom community (Freeman et al., 2007). The vast majority of this research has been conducted with elementary and middle school students. For example, studies with lower grade to higher grade students have supported the need of relatedness and positive effects on cognitive performance and on emotional satisfaction (Baumeister \& Leary, 1995).

When students feel distressed by external factors, they experience introjected regulation, external regulation, and amotivation, whereas they were significantly low on the intrinsic motivation to know. Booker (2008) supported the conclusion that college students' interactions with their professors were important indicators of their performance. Acknowledging that today's classrooms may be different, a study by Endo and Harpel (1982) reported that students process information better as they develop more of a sense of connection with peers and instructor. First year college students were more intrinsically motivated after developing good relations with peers and instructors (Freeman et al., 2007).

Overall, the results supported the hypothesis that positive experiences in the learning environment were related with higher degrees of academic motivation and negative experiences (feeling distressed) were related with the more extrinsic, less autonomous forms of regulation and also with amotivation. The interesting point was that identified regulation (the most autonomous form of extrinsic motivation type just before intrinsic motivation towards accomplishment) was positively correlated with sense of classroom community, whereas intrinsic motivation towards accomplishment did not show significance on any of the measures. This may indicate that students did not enjoy being challenged, even though being challenged is intrinsic to the nature of graduate studies. As an indicator of identified regulation, students may be counting graduate school as an important step to be passed before continuing on to their careers but not purely enjoying it, which is essential to the nature and expected 
purpose of graduate studies especially in a large research university. When we consider the findings from a different perspective, students with positive experiences scored high on both intrinsic motivation (to know) and extrinsic motivation (identified regulation), which clarifies that the hypothesis was supported.

\section{Will international students be more affected than non-international students by the use of culturally local examples or experiences used by the instructor or other students in instruction?}

In the culturally blended learning environment, it is harder to meet the needs of everyone, for both students and instructors. Considering the community, as well as international students, it is also not easy for native speakers to adapt to international students' pronunciation and behaviors. For example, international teaching assistants seem to be at a disadvantage compared to their American colleagues, because even teaching assistants with good English is more likely to make mistakes under pressure or with sudden questions (Li, Mazer \& Ju, 2011). Even though teaching college students is different than simply being in the same class with them; it is possible that some of their peers would also find international students culturally irrelevant or incomprehensible. In addition, for international students, it is possible that they might not enjoy when culture-specific examples are given, because they may not understand the context of these examples.

In general, international students were lower than American students on the external regulation as well as on sense of classroom community. For the item about culture-specific examples, results supported the hypothesis indicating that international students are more affected by culturally local examples used in class. Both at the college level and in graduate classes, international students have communication difficulties with their classmates and sometimes they perceive the host students' behaviors as dismissive and discriminating (Wadsworth, Hecht, \& Jung, 2008). However, international students are ready for the possibility that Americans may have inaccurate knowledge and bias towards their culture, therefore they do not let perceived discrimination affect their academic performance (Wadsworth et al., 2008). In this study, international students were more sensitive to culturally local examples used in class, and they were lower in sense of community. It seems like international students can tolerate inaccuracy but not discrimination or underestimation. When they feel misperceived, it is not possible to feel a part of classroom community emotionally.

\section{Are higher levels of feeling ingroup during a class associated with higher scores on the intrinsic motivation scales and with lower scores on the extrinsic motivation and amotivation subscales?}

With average scores on classroom community and positive support and respect subscales as the ingroup variable, the results revealed that students feeling ingroup reported higher levels of intrinsic motivation (to know, and towards accomplishment) and higher identified regulation. Individuals form groups as a reflection of a part of their own selves and seek compatibility among group members. Tajfel (1974) explained, "It can be assumed that an individual will tend to remain a member of a group and seek membership of new groups if these have some contribution to make to the positive aspects of his social identity; i.e. to those aspects of it from which he derives some satisfaction" (p. 69). In a learning environment, students would be looking for fellow students with similar interests in addition to being supportive, encouraging to one another. Because ingroup identification brings a more positive self-perception, many studies have shown a positive association between ingroup identification and positive outcomes such as well-being, health, performance, and enhanced motivation (Amiot \& Sansfacon, 2011; Laar et al., 2010; Ryan \& Deci, 2003). Also, members of 
informal groups obtain better outcomes (Sheldon \& Bettencourt, 2002). In U.S. universities, the learning environment of graduate schools is usually informal, and, individuals share a common purpose to learn and produce instead of seeking status over one another. Therefore, such an environment would be another factor that would contribute to the enhanced motivation of students.

It is found that perceptions of ingroup were associated with higher levels of both intrinsic and some levels of extrinsic motivations. Within social identity, enhancement of motivation is obtained also by keeping the authenticity of identity. Even individuals who do not belong to ingroup enhance their motivation and performance when group members support them and give them opportunity (Laar et al., 2010). Sheldon and Bettencourt (2002) for the first time used Self Determination Theory in relation to social group differentiation. In their study, autonomy and relatedness were used as the major components to measure group identification and how supportive a group is. They suggested that the more encouraging and respectful to the identity of the members (supporting autonomy) a group is, the more positive outcomes are found.

\section{Are there any differences on the learning community and self-determined motivation subscales between groups representing gender, age levels, disciplines, ethnicity, and years spent in graduate school?}

The analysis of the demographic variables showed that women and men did not differ on their sense of classroom community and academic motivation, but did show some differences on the self-determined motivation scales. However, the majority of studies have claimed that female students are more effective in building relations and community than male students. For example, both in distance learning and blended learning environments, women were more interactive and supportive, whereas men were more critical and formal (Graff, 2003; Rovai, 2001). Therefore, women usually report a higher sense of community relative to men. In a study about students' course drop out and initial motivation towards a course, female students reported higher self-determined motivation (Vallerand \& Bissonette, 1992). There were no gender differences found in this study.

Among age groups, students between the ages of 19-23 were less motivated (amotivation) to be in graduate school when compared to 30-35 and 43-older age groups. The same young group (19-23 years) reported experiencing less support, compared to the 24-29 age group which had the highest support. It is possible that these groups had different reasons for going to graduate school. Students in the youngest age group newly experience the responsibilities of a graduate student life whereas the older groups know what to expect and they chose to return to school with a more conscious choice. Brouse et al. (2010) found a significant decline happened on college students' motivation levels as the years passed, and women always had higher motivation, even during decline.

As to the number of years in graduate school, students were in their $1^{\text {st }}, 2^{\text {nd, }}$ and $5^{\text {th }}$ or more years in graduate school had more support and respect than $4^{\text {th }}$ year students. This result is likely to be because of low sample size of $4^{\text {th }}$ year students relative to others. However, it's also possible that there is more course work in the first years so students have more chance to see one another and have more shared experiences. In the last years, they probably are more involved in research and are not in class that much. Partly supporting this study's results, in an attempt to define international students' isolation in a U.S. campus, Erichsen and Bolliger (2011) reported that first year students and master's students were more tolerant to the self, and they reported less isolation than students in further grades, supporting one of the findings 
of my study. As well as second and third year students, women also perceived less respect and support as an addition to previous findings.

As to the discipline variable, education majors were higher on intrinsic motivation to experience stimulation than engineering students, and natural science majors were the lowest on that measure. Additionally, education majors were the highest on identified regulation followed by natural sciences and then engineering majors. For all majors, identified regulation was stronger than intrinsic motivation to experience stimulation. Natural science majors seemed affected the most by their emotions as reflected in their low levels of intrinsic motivation.

Finally, as for the ethnicity variable, European descent white students $(n=177)$ had significantly higher scores on the classroom community measure than non-European descent students $(n=77)$. Perhaps because European descent white students represented a higher percentage of their classes, it may be easier for them to build community. As hypothesized, the international students $(n=45)$ had lower scores on measure of classroom community and higher scores of external regulation than non-international students. This supports my idea that the more fulfillment of relatedness will be associated with less extrinsic motivation. And again the difference in sample size for the two groups may have influenced the findings. In U.S. academic programs international students have reported academic and social isolation in graduate school, and a low sense of classroom community both in their traditional and online classes (Erichsen \& Bolliger, 2011). In their study investigating students' connectedness to their campus, Summers et al. (2002) also did not find any difference among ethnic groups. However, women had higher scores than men, sophomores had a lower sense of connection than seniors, and natural science majors had the lowest sense of campus community.

\section{CONCLUSION}

Overall, the results of this study suggested that classroom community and positive respect and support from peers and instructors are important for the fulfillment of basic needs of students in a learning environment, associated their motivation greatly. When students feel they are a part of the learning environment and perceive kind and encouraging behaviors around them, they feel ingroup. This directly influences their performance by motivating them to learn and accomplish, or at least to see the importance and value of their work. Among these graduate students, international students particularly seemed more sensitive to the use of cultural examples, and had more difficulty forming a sense of classroom community.

\section{RECOMMENDATIONS}

This study takes a step to extend the literature and to investigate graduate students' experiences. Further research is needed about graduate students, their motivation, well-being, and their interactions. In the future, studies of social identity in particular should be considered as an important separate construct, using multiple methods. It is important to focus on a specific course and instructor, using quantitative and qualitative methods together. In an attempt to reveal the perceptions towards and of international students, it would be interesting to use different theories such as Communication Theory of Identity (Wadsworth et al., 2008). Qualitative investigations, observations, creative social experiments would also bring necessary insights. Common usage of online tools such as Blackboard in U.S. provides an opportunity for the representations of identities and allows individuals to communicate with each other. It can be considered to investigate both the instructors' perception, and the student's to have a fuller view representation. If these are done in comparison to face-to-face classroom experiences, with in depth interviews, and with observations as well as quantitative data, we would have invaluable insights of learners' world. 
All in all, this study had many limitations however; it showed promise for further investigation with a multi-structured research. The findings will be helpful for both students and instructors to be sensitive about the examples they use in class. Our behaviors are really impactful in the learning environment. In addition, usage of cultural examples is important so giving more voice to students to present their own examples may be helpful to boost the sense of community. It is important to realize that graduate students are not much different than other learners and they have fluctuating motivations. Hence, it is important to support them and to build an environment in which students and instructors respect one another for better outcomes.

\section{References}

Amiot, C. E., \& Sansfaçon, S. (2011). Motivations to identify with social groups: A look at their positive and negative consequences. Group Dynamics: Theory, Research, and Practice, 15(2), 105-127.

http://dx.doi.org/10.1037/a0023158

Baumeister R. F., \& Leary M. R. (1995). The need to belong: desire for interpersonal attachments as a fundamental human motivation. Psychological Bulletin, 117(3), 497-529.

Beachboard, M. R., Beachboard, J. C., Li, W., \& Adkison, S. R. (2011). Cohorts and relatedness: Self-determination theory as an explanation of how learning communities affect educational outcomes. Research in Higher Education, 52(8), 853-874.

Booker, K. C. (2008). The role of instructors and peers in establishing classroom community. Journal of Instructional Psychology, 35(1), 12-17.

Bowman, R. L., \& Bowman, V. E. (1990). Mentoring in a graduate counseling program: Students helping students. Counselor Education \& Supervision, 30(1), 58-65.

Brouse, C. H., Basch, C. E., Leblanc, M., McKnight K. R. \& Lei T. (2010). College students' academic motivation : Differences by gender, class, and source of payment. College Quarterly,13(1), 1-10.

Bush, A. M., Svinicki, M. D., Achacoso, M. V., \& Kim, M. (2004, April). Creating Classroom Community: Student and Instructor Variables. Paper presented at the American Education Research Association, San Diego.

Bush, A. M. (2006). What comes between classroom community and academic emotions: Testing a self-determination model of motivation in the college classroom. The University of Texas at Austin. ProQuest Dissertations and Theses, http://ezproxy.lib.utexas.edu/login?url=http://search.proquest.com/docview/304984107?accountid=7118.

Deci, E. L., Vallerand, R. J., Pelletier, L. G., \& Ryan, R. M. (1991). Motivation and education: The self-determination perspective. Educational Psychologist, 26 (3\&4), 325-346.

Endo, J. J., \& Harpel, R. L. (1982). The effect of student faculty interactions on students' educational outcomes. Research in Higher Education, 16, 115-135.

Erichsen, E. a., \& Bolliger, D. U. (2011). Towards understanding international graduate student isolation in traditional and online environments. Educational Technology Research and Development, 59(3), 309-326.

Faye, C., \& Sharpe, D. (2008). Academic motivation in university: The role of basic psychological needs and identity formation. Canadian Journal of Behavioral Science 40(4), 189-199.

Freeman, T. M., Anderman, L. H., \& Jensen, J. M. (2007). Sense of belonging in college freshmen at the classroom and campus levels. The Journal of Experimental Education, 75(3), 203-220.

Goplerud, E. N. (1980). Social support and stress during the first year of graduate school. Professional Psychology, 11(2), 283-290.

Graff, M. (2003). Individual differences in sense of classroom community in a blended learning environment. Journal of Educational Media, 28(2\&3), 203-210.

Hegarty, N. (2011). Adult learners as graduate students: Underlying motivation in completing graduate programs. The Journal of Continuing Higher Education, 59(3), 146-151.

Laar, C. V., Derks, B., Ellemers, N., \& Bleeker, D. (2010). Valuing social identity: Consequences for motivation and performance in low-status groups. Journal of Social Issues, 66(3), 602-618.

Li, L., Mazer, J. P., \& Ju, R. (2011). Resolving international teaching assistant language inadequacy through dialogue: Challenges and opportunities for clarity and credibility. Communication Education, 60(4), 461-478. 
Noddings, N. (2005). The challenge to care in schools: An alternative approach to education. New York, NY: Teachers College Press.

Osterman, K. F. (2000). Students' need for belonging in the school community. Review of Educational Research, 70, 323-367.

Reeve, J. (2009). Understanding Motivation and Emotion. NJ: John Wiley \&Sons, Inc.

Rovai, A. P. (2001). Building classroom community at a distance : A case study, Educational Technology Research and Development, 49(4), 33-48.

Ryan, R., \& Deci, E. (2000). Intrinsic and extrinsic motivations: classic definitions and new directions. Contemporary Educational Psychology, 25(1), 54-67.

Ryan, R. M., \& Deci, E. L. (2000). Self-determination theory and the facilitation of intrinsic motivation, social development, and well-being. The American Psychologist, 55(1), 68-78.

Ryan, R. M., \& Deci, E. L. (2003). On assimilating identities to the self: A self-determination theory perspective on internalization and integrity within cultures. In M. R. Leary \& J. P. Tangney (Eds.), Handbook of self and identity (pp. 253-274). New York: The Guilford Press.

Ryan, R. M., \& Deci, E. L. (2008). Self-determination theory and the role of basic psychological needs in personality and the organization of behavior. In O. P. John, R. W. Robbins, \& L. A. Pervin (Eds.), Handbook of personality: Theory and research (pp. 654-678). New York: The Guilford Press.

Schmitt, M. T. \& Spears, R. \& Branscombe N. (2003). Constructing a minority group identity out of shared rejection: The case of international students. European Journal of Social Psychology, 33, 1-12.

Sheldon, K. M., \&Bettencourt, B. A. (2002). Psychological need-satisfaction and subjective well-being within social groups. British Journal of Social Psychology, 41, 25-38.

Sheldon, K. M., \& Schüler, J. (2011). Wanting, having, and needing: Integrating motive disposition theory and selfdetermination theory. Journal of Personality and Social Psychology, 101(5), 1106-1123.

Summers, J. J., Svinicki, M. D., Gorin, J. S., \& Sullivan, T. A. (2002). Student feelings of connection to the campus and openness to diversity and challenge at a large research university : Evidence of progress. Innovative Higher Education, 27(1), 53-64.

Summers, J. J., Beretvas, S. N., Svinicki, M. D., \& Gorin, J. S. (2005). Evaluating community and collaborative learning. Journal of Experimental Education, 165-188.

Sungur, S., \& Senler, B. (2010). Students' achievement goals in relation to academic motivation, competence expectancy, and classroom environment perceptions. Educational Research and Evaluation, 16(4), 303-324.

Tajfel, H. (1974). Social identity and intergroup behavior. Social Science Information, 13(2), 65-93.

Tajfel, H., \& Turner, J. C. (1979). An integrative theory of intergroup conflict. In W. G. Austin \& S.Worchel (Eds.), The social psychology of intergroup relations (pp. 33-47). Monterey, CA: Brooks/Cole.

Turner, J. C., Hogg, M. A., Oakes, P. J., Reicher, S. D., \& Wetherell, M. S. (1987). Rediscovering the social group: A selfcategorization theory. Oxford, UK: Blackwell.

Vallerand, R. J., Pelletier, L. G., Blais, M. R., Briere, N. M., Senecal, C., \& Vallieres, E. F. (1992). The academic motivation scale: a measure of intrinsic, extrinsic, and amotivation in education. Educational and Psychological Measurement, 52(4), 1003-1017.

Vallerand, Robert J, \& Bissonnette, R. (1992). Intrinsic, extrinsic, and amotivational styles as predictors of behavior : A prospective study. Journal of Personality 60(3), 599-620.

Wadsworth, B. C., Hecht, M. L., \& Jung, E. (2008). The role of identity gaps, discrimination, and acculturation in international students' educational satisfaction in American classrooms. Communication Education, 57(1), 64-87.

Woodruff, A. L., \& Schallert, D. L. (2008). Studying to play, playing to study: Nine college student-athletes' motivational sense of self. Contemporary Educational Psychology, 33(1), 34-57. 